\title{
Tumor Identifier Group Identifier
}

National Cancer Institute

\section{Source}

National Cancer Institute. Tumor Identifier Group Identifier. NCI Thesaurus. Code C117434.

A character or string that represents a tumor identifier group. 